\title{
Rescue of the streptomycin antibiotic activity by using streptidine as a “decoy acceptor" for the aminoglycoside inactivating enzyme adenyl transferase
}

\author{
Montserrat Latorre, Pablo Peñalver, Julia Revuelta, Juan Luis Asensio, Eduardo García-Junceda* and \\ 5 Agatha Bastida*
}

\author{
Receipt/Acceptance Data [DO NOT ALTER/DELETE THIS TEXT] \\ Publication data [DO NOT ALTER/DELETE THIS TEXT] \\ DOI: 10.1039/b000000x [DO NOT ALTER/DELETE THIS TEXT]
}

The use of streptidine as a "decoy acceptor" allows the 10 antibiotic activity of streptomycin to recover against the $\boldsymbol{E}$. coli strain overexpressing the aminoglycoside-modifying enzyme 6O-adenyl transferase.

Emergence of bacterial resistance for all classes of antipathogenic agents has become a serious problem over recent years. ${ }^{1}$

15 Aminoglycosides were one of the first groups of antibiotics to meet the challenge of resistance. ${ }^{2}$ Acquired resistance to aminoglycoside antibiotics can occur via three different mechanisms: ${ }^{3}$ Mutation of the ribosomal target, reduced permeability for the antibiotics and enzymatic modification of the

20 drugs leading to inactivation. The most prevalent source of clinically relevant resistance is conferred by the third mechanism, the enzymatic inactivation of the drugs. ${ }^{4}$ There are well over 50 aminoglycoside-modifying enzymes (AME) that have been characterized at gene level. ${ }^{5}$ Genes encoding for these enzymes

25 can be found on the bacterial chromosome, on broad-host-range plasmids or integrated into transposons. These characteristics facilitate the quick dissemination of these genes. ${ }^{6}$ The AME can be classified as $\mathrm{N}$-acetyltransferases (AACs), O-adenyl transferases (ANTs) and O-phosphotransferases (APHs). In each

30 of these families are several enzymes that catalyze the reactions with different regioselectivity and substrate specificity. There is strong evidence that inhibitors of AME have the potential to reverse resistance and rescue antibiotic activity ${ }^{7}$ if they are administered together with existing aminoglycosides, following a

35 methodology well established for $\beta$-lactam antibiotics. ${ }^{8}$ However, a deeper knowledge of the molecular mechanism of the AME and of their structures and interactions with the drugs, is needed to facilitate the design either of effective and potent inhibitors, or of novel aminoglycosides, not susceptible to modification by

40 these enzymes. ${ }^{9}$

ANT family is the smallest of the three groups with only 10 enzymes identified to date, including enzymes that regioselectively adenylate the 6 and 3'" positions of the streptomycin (1) and the 9 and 3' positions of the

45 spectinomicyn. $^{7}$ Up to now, only the 3D structure of the Staphylococcus aureus ANT(4'), has been determined. ${ }^{10}$

In our group, we are involved in the overexpression and physico-chemical characterization of aminoglycoside modifying

Departamento de Química Orgánica Biológica, Instituto de Química Orgánica General, CSIC, Madrid 28006, Spain. Fax: +34-915 644 853; Tel: +34-915 622 900. E-mail: agatha.bastida@iqog.csic.es eduardo.junceda@iqog.csic.es. enzymes. For this reason, we have overexpressed the aadk gene 50 from Bacillus subtilis by cloning it in the pET28-b(+) vector. The vector pET-aadk-his ${ }_{6}$ was transformed in the E. coli BL21 (DE3) strain and the recombinant protein purified by $\mathrm{Ni}^{2+}$ affinity column $^{11}$. The activity of the pure ANT(6) (Scheme 1) was followed by HPLC and the identity of the adenylated product (2) 55 was confirmed by ${ }^{1} \mathrm{H}-\mathrm{NMR}{ }^{12}$.

Here, we report the use of streptidine (3) as a "decoy acceptor" of the ANT(6) to rescue the antibiotic activity of streptomycin (1) against bacterial strains overexpressing this aminoglycosidemodifying enzyme.

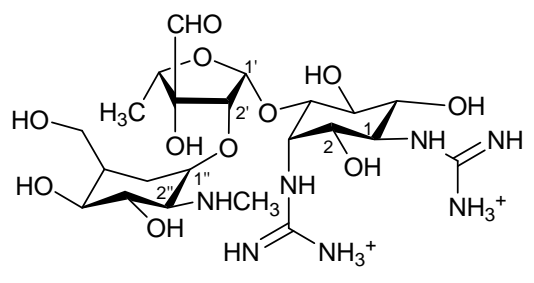
1

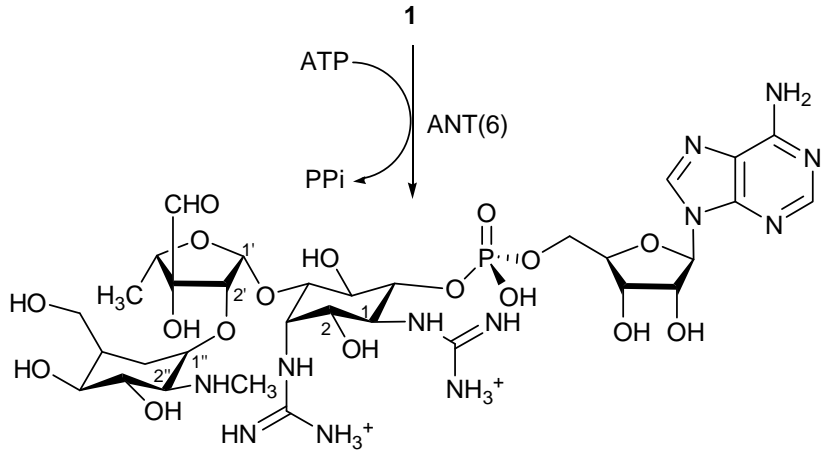

2

Scheme 1 Recombinant ANT(6) catalyze adenylation of streptomycin (1). Typical reaction conditions are ATP $(10 \mathrm{mM})$, Streptomycin $(10 \mathrm{mM})$, $\mathrm{MgCl}_{2}(10 \mathrm{mM})$, ANT(6) $(10 \mu \mathrm{M})$ in Tris-HCl buffer (50 mM, pH 7.5).

60 In our previous paper, ${ }^{12}$ the antibiotic recognition epitope was determinated by STD-NMR (Saturation Transfer Spectroscopy) experiments. The data obtained indicates that positions 1 and 6 in the streptidine moiety are in close contact with the protein binding site. In order to investigate if the streptidine (3) could be

65 O-adenylated by the recombinant enzyme, we obtained the streptidine (3) by acid methanolysis of the streptomycin (1) with $\mathrm{H}_{2} \mathrm{SO}_{4} / \mathrm{MeOH}^{13}$ (Scheme 2). The streptidine was subjected to 


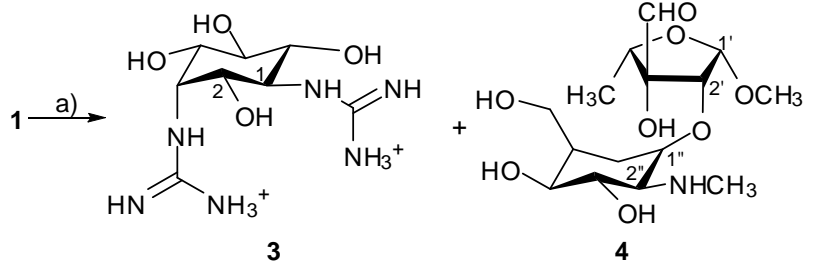

Scheme 2 Acid methanolysis of streptomycin (1) gives streptidine (3) and methyl dihydrostreptobiosaminidine (4). a) $0.5 \mathrm{~g}$ of $\mathbf{1}$ was dissolved in 4 $\mathrm{mL}$ of $\mathrm{MeOH}$ containing $0.15 \mathrm{~mL}$ of $\mathrm{H}_{2} \mathrm{SO}_{4}$. After $48-72 \mathrm{~h}$ at room temperature, streptidine (3) appears as a white precipitate.

enzymatic adenylation with ATP and recombinant ANT(6). Formation of the adenylated product (AMP-streptidine) was

70 confirmed by ${ }^{1} \mathrm{H}-\mathrm{NMR},{ }^{13} \mathrm{C}-\mathrm{NMR}$ and (ES+) $\mathrm{m} / \mathrm{z}^{14}$ The most relevant kinetic parameters for the recombinant ANT(6) are summarized in Table 1 . This data strongly suggests that the enzyme presents higher affinity for streptomycin than for streptidine ( the two $K_{M}$ values differ in one order of magnitude)

75 which was expected.

Table 1. Kinetic parameters of the ANT(6) from Bacillus subtilis.

\begin{tabular}{|c|c|c|c|}
\hline Substrate & $\begin{array}{c}\mathrm{V}_{\max } \\
(\mu \mathrm{mol} / \mathrm{min} / \mathrm{mg})\end{array}$ & $\begin{array}{c}\mathbf{K}_{\mathbf{M}} \\
(\mathbf{m M})\end{array}$ & $\begin{array}{r}k_{\mathrm{cat}} / \mathbf{K}_{\mathrm{M}} \\
\left(\mathrm{s}^{-1} \times \mathbf{M}^{-1}\right)\end{array}$ \\
\hline Streptomycin & 0,06 & 0,04 & $9,2 \times 10^{2}$ \\
\hline Streptidine & 0,0012 & 0,6 & 1,2 \\
\hline
\end{tabular}

All enzymatic reactions were carried out at: $\mathrm{pH}=7.5 ; 25^{\circ} \mathrm{C}$ and 10 $\mu \mathrm{M}$ of enzyme. The concentration of ATP and $\mathrm{MgCl}_{2}$ was fixed at $10 \mathrm{mM}$ when the concentration of streptomycin and streptidine was modified.

In view of this result, we decided to explore if streptidine could act in vivo as a "decoy acceptor" of the ANT(6) allowing the streptomycin activity to recover (Table 2).

Streptomycin is a powerful antibiotic with a $\mathrm{MIC}^{\dagger}$ of $5 \mu \mathrm{g} / \mathrm{mL}$ 80 for the E. coli BL21(DE3) strain. However, as expected, when the aminoglycoside-modifying enzyme ANT(6) was overexpressed streptomycin completely lost its antibiotic activity (MIC $>200 \mu \mathrm{g} / \mathrm{mL}$ ). On the other hand, streptidine did not show any antibiotic activity either in presence or absence of ANT(6)

85 (MIC $>400 \mu \mathrm{g} / \mathrm{mL}$ ). When streptomycin and streptidine were co-

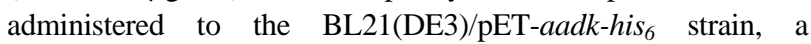
significant decrease in the streptomycin MIC value was observed (Table 2). Thus, when the antibiotic was administered with 50 $\mu \mathrm{g} / \mathrm{mL}$ of streptidine, its MIC value dropped to $50 \mu \mathrm{g} / \mathrm{mL}$, but if

90 the concentration of streptidine was increased to $400 \mu \mathrm{g} / \mathrm{mL}$ the MIC for streptomycin lowered to $10 \mu \mathrm{g} / \mathrm{mL}$, recovering its antibiotic activity to a great extent. The streptidine/streptomycin

Table 2 In vivo activity ${ }^{\mathrm{a}}$ of streptomycin (1) alone or in combination with streptidine (3) against E. coli strains expressing or not the ANT(6).

\begin{tabular}{lccc}
\hline \multicolumn{1}{c}{ Strain } & $\mathbf{1}$ & $\mathbf{3}$ & $\mathbf{1}+\mathbf{3}$ \\
\hline BL21(DE3) & 5 & $>400$ & 5 \\
BL21(DE3)/pET-aadk-his 6 (ANT(6)) & $>200$ & $>400$ & $50(10)^{\mathrm{b}}$
\end{tabular}

${ }^{a}$ Activity of the aminoglycoside antibiotics is expressed by the MIC value $(\mu \mathrm{g} / \mathrm{mL})$. ${ }^{\mathrm{b}} \mathrm{MIC}$ values for streptomycin in presence of 50 or $400 \mu \mathrm{g} / \mathrm{mL}$ of streptidine. ratio of 40/1 needed to recover the antibiotic activity of the streptomycin in vivo, is lower than the difference between the

$95 k_{\text {cat }} / K_{\mathrm{M}}$ of ANT(6) with both substrates. This could be due to the fact that the simultaneous presence of streptidine and/or AMPstreptidine can limited the overall rate of the reaction with streptomycin.

In conclusion, we have shown that the streptidine moiety of 100 streptomycin, is a substrate for the aminoglycoside inactivating enzyme ANT(6). The addition of this molecule in cell culture restores the activity of the streptomycin antibiotic normally inactivated by the ANT(6) enzyme, because the streptidine competes with the streptomycin acting as a "decoy acceptor" of

105 the ANT(6). Thus, streptidine can be a good starting compound for the design of more efficient "decoy acceptor" of aminoglycoside-modifying enzymes.

This work was supported by the Spanish Ministerio de Educación y Ciencia (Grant CTQ2004-03523/BQU). M.L. 110 thanks to regional government of Madrid for the award of a predoctoral fellowship. The authors acknowledge Dr. P. Armisen for the $\mathrm{Ni}^{2+}$-IDA-agarose gift.

\section{Notes and references}

$\uparrow$ Minimal inhibitory concentration (MIC) was measured according to a 115 published method. ${ }^{15}$ E. coli BL21(DE3) was grown in $1 \mathrm{~mL}$ of MuellerHinton broth to an optical density $\left(\mathrm{OD}_{600}\right)$ of 0.5 units. The desired concentrations of antibiotic were added from stock solutions. After incubation at $37^{\circ} \mathrm{C}$ for $24 \mathrm{~h}$. the $\mathrm{OD}_{600}$ of each sample was read. In the case of the recombinant strain BL21(DE3)/pET-aadk-his 6 , the

120 described protocol was slightly modified. The bacteria was grown in 1 $\mathrm{mL}$ of Mueller-Hinton broth to an $\mathrm{OD}_{600}$ of 0.3 units. Then, temperature was switched to $30^{\circ} \mathrm{C}$, and the culture was induced with $0.5 \mathrm{mM}$ IPTG. When the $\mathrm{OD}_{600}$ reached 0.5 units, the desired concentrations of antibiotic were added. The samples were incubated at $30^{\circ} \mathrm{C}$ for $24 \mathrm{~h}$. In

125 both cases, the MIC was taken as the lowest antibiotic concentration inhibiting bacterial growth by greater than $90 \%$.

1 C. A. Smith and E. N. Baker, Current Drug Targets - Infectious Disorders, 2002, 2, 143.

1302 G. D. Wright, Curr. Op. Microbiol. 1999, 2, 499.

3 J. D. Hayes and C. R. Wolf, Biochem. J., 1990, 272, 281; G. A. Jacoby and G. C. Archer, N. Engl. J. Med., 1991, 324, 601; H. C. Neu, Science, 1992, 257, 1064.

1354 J. Davies, G. D. Wright, Trends Microbiol., 1997, 5, 234; G. D. Wright, in Bacterial Resistance to Antimicrobials, ed. K. Lewis, A. A. Salyers, H. W. Taber and R. G. Wax, Marcel Dekker, New York, 2002, pp. 91-121.

5 D. M. Daigle, G. A. McKay and G. D. Wright, J. Biol. Chem., 1997, 272, 24755.

$1406 \quad$ K. J. Shaw, P. N. Rather, R. S. Hare and G. H. Miller, Microbiol. Rev., 1993, 57, 138.

7 S. Magnet and J. S. Blanchard, Chem. Rev., 2005, 105, 477.

8 R. N. Jones and D. M. Johnson, Clin. Microbiol. Infect., 1995, 1, 86; R. Sutherland, Infection, 1995, 23, 191; C. Thorburn, S.

145 Molesworth, R. Sutherland, S. Rittenhouse, Antimicrob. Agents Chemother., 1996, 40, 2796.

9 J. L. Asensio, A. Hidalgo, A. Bastida, M. Torrado, F. Corzana, E. García-Junceda, J. Cañada, J. L. Chiara and J. Jimenez-Barbero, J. Am. Chem. Soc., 2005, 127, 8278; A. Bastida, A. Hidalgo, J. L. Chiara, M. Torrado, F. Corzana, J. M. Cañadillas, P. Groves, E. García-Junceda, J. Jimenez-Barbero, and J. L. Asensio, J. Am. Chem. Soc. 2006, 128, 100.

10 J. Sakon, H. H. Liao, A. M. Kanikula, M. M. Benning, I. Rayment and H. M. Holden, Biochemistry, 1993, 32, 11977; L. C. Perdersen, M. M. Benning and H. M. Holden, Biochemsitry, 1995, 34, 13305. 
11 A complete account of the cloning, over expression and biochemical characterization of the recombinant ANT(6), will be published elsewhere.

16012 F. Corzana, I. Cuesta, A. Bastida, A. Hidalgo, M. Latorre, C. Gonzalez, E. García-Junceda, J. Jiménez-Barbero, and J. L. Asensio, Chem. Eur. J., 2005, 11, 5102.

13 R. L. Peck, R. P. Graber, A. Walti, E. W. Peel, C. E. Hoffhine, K. Folkers, J. Am. Chem. Soc., 1946, 68, 29. Streptidine; ${ }^{1} \mathrm{H}-\mathrm{NMR}$

165 (500 MHz, $\left.\mathrm{D}_{2} \mathrm{O}, \mathrm{pH}=3,0 \delta 3.25-3.45 \mathrm{~m}, 6 \mathrm{H}\right)$ and $\mathrm{MS}(\mathrm{ES}+) \mathrm{m} / \mathrm{z}$ $263[\mathrm{M}+\mathrm{H}]^{+}$.

14 AMP-streptidine: ${ }^{1} \mathrm{H}-\mathrm{NMR}\left(\mathrm{D}_{2} \mathrm{O}\right.$ at $\left.500 \mathrm{MHz}, \mathrm{pH}=3,0\right), \delta=1.06$ (t, $1 \mathrm{H}, \mathrm{J}=7.1 \mathrm{~Hz}) 3.45(\mathrm{~m}, 5 \mathrm{H}) 3.90$ (dd, $1 \mathrm{H}, \mathrm{J}=9.3 \mathrm{~Hz}, \mathrm{~J}=18.8 \mathrm{~Hz})$ $4.09(\mathrm{~m}, 1 \mathrm{H}) 4.18(\mathrm{~d}, 1 \mathrm{H}, \mathrm{J}=1.6 \mathrm{~Hz}) 4.27(\mathrm{~m}, 1 \mathrm{H}) 4.31(\mathrm{~s}, 1 \mathrm{H})$

$1704.39(\mathrm{t}, 1 \mathrm{H}, \mathrm{J}=4.56 \mathrm{~Hz}) 4.45(\mathrm{t}, 1 \mathrm{H}, \mathrm{J}=5.4 \mathrm{~Hz}) 6.07(\mathrm{~d}, 1 \mathrm{H}$, $\mathrm{J}=5.2 \mathrm{~Hz}) 8.34$ (d, $1 \mathrm{H}, \mathrm{J}=4.5 \mathrm{~Hz}) 8.52(\mathrm{t}, 1 \mathrm{H}, \mathrm{J}=5.7 \mathrm{~Hz})) .{ }^{13} \mathrm{C}$ NMR $\left(\mathrm{D}_{2} \mathrm{O}\right.$ at $125 \mathrm{~Hz},:$ 15.3, 58.2, 59.0, 65.5, 70.2, 70.6, 71.6, 74.3, 77.1, 84.3, 88.2, 145.3, 158.0, 158.3). MS (ES+) m/z (\%): 592,2 $[\mathrm{M}+\mathrm{H}]+$.

17515 P. M. Waterworth, in Laboratory Methods in Antimicrobial Chemotherapy, ed. L. Garrod, Churchill Livingstone Press, Edinburgh, 1978, pp 31-40. 